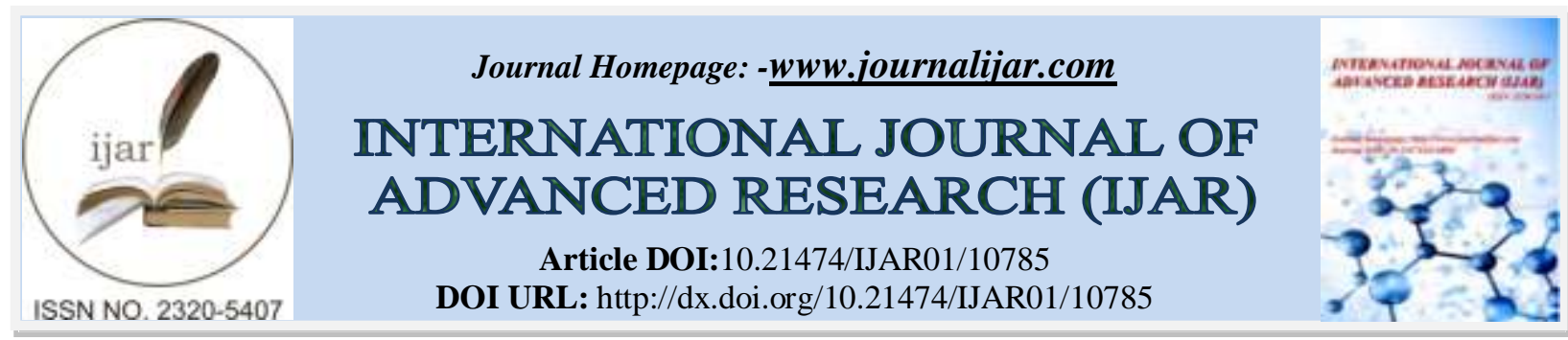

RESEARCH ARTICLE

\title{
IRRIGATTION WATER PRODUCTIVITY EVALUATION OF TOMATO IN THE NORTHERN NIAYES
} AREA IN SENEGAL

\author{
A. Sané ${ }^{1}$, L. Diop ${ }^{1}$, A. Sarr ${ }^{1,2}$, Y.D. Wane ${ }^{1}$, I. Diatta ${ }^{3}$, M.D. Diallo ${ }^{1}$, A. Bodian ${ }^{4}$ and S.M. Seck $^{3}$ \\ 1. Agronomic Sciences, Aquaculture and Food Technology (S2ATA) UFR, Gaston Berger University, Saint- \\ Louis, Senegal. \\ 2. Irrigated agriculture, Mediterranean Agronomic Institute of Bari (CIHEAM-BARI), Bari, Italy. \\ 3. Interdisciplinary Research Group in Support of Regional Planning and Local Development, Gaston Berger \\ University, Saint-Louis, Senegal. \\ 4. Arts and Humanities UFR, Gaston Berger University, Saint-Louis, Senegal.
}

\section{Manuscript Info}

Manuscript History

Received: 10 February 2020

Final Accepted: 12 March 2020

Published: April 2020

Key words:-

Water Productivity, Irrigation, Tomato,

Yield, Water Supplied, North-Niayes

\begin{abstract}
In the Niayes, irrigation of market garden crops is totally ensured by groundwater, which is the only available water source used in irrigation. However, this water source is vulnerable to the development of irrigated agriculture and the impact of climate change. This raises the challenge of optimizing irrigation in this area. The objective of this study is to evaluate tomato irrigation water productivity in the Lowlands of DeurDiabi, Lac Kalassane, FersetNdoye, BoulAyni and Nguéthiouro in the Niayes. In this regard, surveys were carried out with 123 farmers in these five lowlands, focusing on irrigation management at plot level. The volumes of irrigation water supplied per plot and the yields are calculated on the basis of these surveys. Water productivity was determined based on water volumes supplied and yields. Results showed that the volumes of water supplied are very high compared to crop water requirements and yields are relatively low. Water quantities applied per season varied between $3330 \mathrm{~m} 3 / \mathrm{ha}$ and $5000 \mathrm{~m} 3 / \mathrm{ha}$ and yields varied between $18 \mathrm{t} / \mathrm{ha}$ and $27 \mathrm{t} / \mathrm{ha}$. Thus, tomato water productivity is varied between 5.00 and $5.96 \mathrm{~kg} / \mathrm{m} 3$ with an average of $5.18 \mathrm{~kg} / \mathrm{m} 3$. These results show that tomato water productivity in this area is very low and has to be improved. These results can be of great contribution to irrigation optimization.
\end{abstract}

Copy Right, IJAR, 2020,. All rights reserved.

Introduction:-

The world is facing the challenge of rapid population growth. In 2006, the world's population was estimated at 6 billion people. However, it is projected to increase to about 8.1 billion by 2030 , representing $35 \%$ growth (Playan and Mateos, 2006). However, 95\% of this expansion is projected to originate in developing countries (OECD/FAO, 2016). Sub-Saharan Africa will be the area most affected by population growth. Indeed, population growth in subSaharan Africa is estimated at $2.7 \%$ per year between 2016 and 2025, resulting in an increase in population from 0.96 billion to 1.22 billion over the same period (OECD/FAO, 2016). This growth of the world population is correlated with additional demand for food and developing countries are considered to be the main drivers of this additional global demand for agricultural products over the next decade. Indeed, it is expected that food needs of the 
world's population in 2050 will be $60 \%$ higher than in 2005 . However, this increase will be more significant in subSaharan Africa, whose population's demand for cereals will have to be three times higher than population needs in 2005 (Van Ittersum et al., 2016).

For this purpose, an increase in food production must be achieved through efficient and sustainable agriculture. Agriculture should be classified in first place for achieving food security (FAO, 2001). An FAO analysis of 93 developing countries predicts that global agricultural production will increase by $49 \%$ in rainfed systems and $81 \%$ in irrigated systems between 1998 and 2030 (Playan and Mateos, 2006). However, rain-fed agriculture, which provides the largest share of global food production, is menaced by the potential increase in future climate variability and rainfall scarcity (Rowhani et al., 2011). For example, agricultural production in sub-Saharan Africa is particularly vulnerable to the effects of climate change since rainfed agriculture accounts for $96 \%$ of total agricultural production (Serdeczny et al., 2016). Increases in temperature and decreases in rainfall resulting from the effects of climate change are likely to negatively impact farmers' livelihoods in some Sahelian and sub-Saharan African countries, including Senegal (Yunana et al., 2017).

Therefore, irrigated agriculture is needed to meet crop water requirements for an entire season. Irrigated agriculture is by far the largest user of freshwater, accounting for about 70\% of global withdrawals (FAO, 2011). In Senegal, it was estimated at 2,221 Million $\mathrm{m}^{3}$, water consumption from water resources in 2002 of which $93 \%$ was for agriculture (FAO, 2005). However, water resource utilization for irrigation purposes has consequences. It negatively impacts water resources in some areas, such as Niayes region. In fact, Niayes zone occupies an important position in Senegal's economy. It ensures production of nearly $80 \%$ of the market garden products used at national scale (Fall and Fall, 2001) and includes 65\% of farms (Ndiaye et al., 2012). However, horticultural production is associated with intensive exploitation of water resources. Water used in irrigation in this area comes mainly from groundwater. However, in recent years, this water source has been subject to some degradation due to its intensive use for irrigation. In 2002, it was estimated that $10.6 \%$ of the annual water abstraction from groundwater was used for irrigation of horticultural products for an area of 28.93 ha in the Niayes area. As a result, the quantities of water used for irrigation have become far above renewable resources (HORTICA, 2004). Thus, it is important to improve water productivity in this area.

Over the past decade, agricultural water productivity has been the subject of numerous studies. These have been carried out by international institutions such as the International Water Management Institute (IWMI), the international water research center attached to the Consultative Group on International Agricultural Research (CGIAR) and the Food and Agriculture Organization of the United Nations (FAO) (Molden et al., 2007). Several studies have been conducted to assess water productivity. These studies have very often been conducted to compare irrigation systems. For example, it has been shown that tomato productivity varies between 5 and $20 \mathrm{~kg} / \mathrm{m} 3$ (Molden et al., 2010). This productivity was estimated at $9.3 \mathrm{~kg} / \mathrm{m} 3$ in Southern Togo (Arouna et al., 2018). Also, it was estimated at $10.58 \mathrm{~kg} / \mathrm{m} 3$ in the Nile Delta in Egypt (El-Marsafawy et al., 2018).

However, to our knowledge, there is no study on tomato water productivity in the Niayes area, even though this crop is the second most important horticultural crop and the third most exported horticultural product in Senegal (ANSD, 2017). It is in this context that this present study aims to evaluate the productivity of tomato irrigation water in the market gardening lowlands of Gandiolais.

\section{Materials andMethods:-}

\section{Study area:}

This study was conducted in the Gandiolais area which is located in the northern limit of the Niayes, between Gandon and NdiébèneGandiol communes (Figure 1). More specifically, it concerns five (05) market gardening lowland in five (05) villages distributed between these two communes:

1. Gandon: Deur Diabi (Rao Peul), BoulAyni(KeurSaër),

2. NdiébèneGandiol: Lac Kalassane (Kalassane), FersetNdoye (Ndoye Diagne), Nguéthiouro (Pelour 1 Mbotilme). 


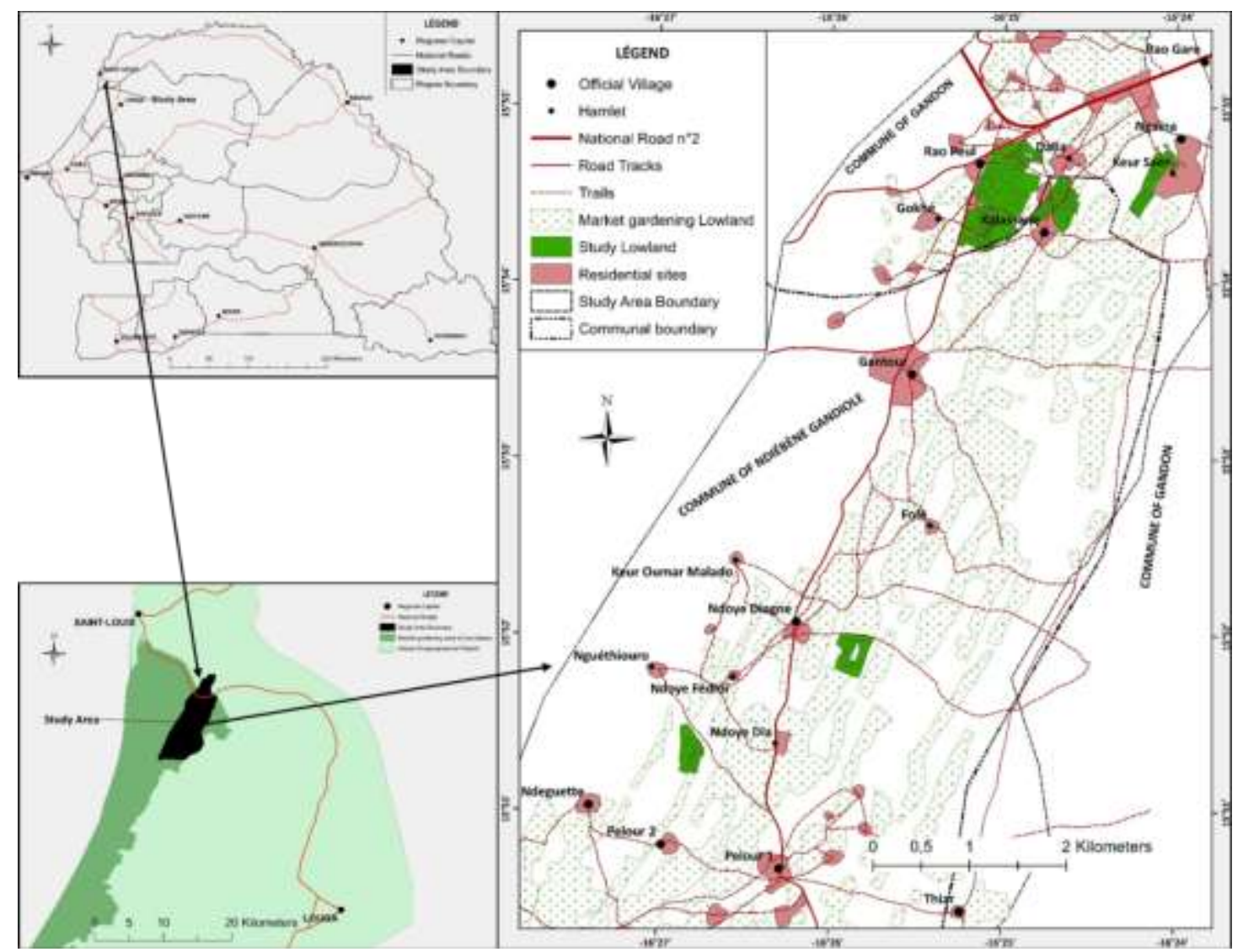

Figure 1:- Location of the study area.

\section{Climate of the study area:}

Climate in the study area is Sahelian with a long dry season from October to June and a short rainy season of three months. Average annual precipitation is low and rarely exceeds $300 \mathrm{~mm} / \mathrm{year}$ (ANACIM, 2016). Moderate temperatures are influenced by circulation of maritime trade winds blown by cold currents from the north (Azores). Average annual temperatures are between $23.7^{\circ} \mathrm{C}$ and $25^{\circ} \mathrm{C}$. The highest average monthly temperatures are between $35^{\circ} \mathrm{C}$ and $37^{\circ} \mathrm{C}$ and occur during rainy season. From November to February, minimum and maximum temperatures are below $18^{\circ} \mathrm{C}$ and $28^{\circ} \mathrm{C}$ respectively (ANACIM, 2016). Harmattan raises early winter temperatures to a maximum of $31^{\circ} \mathrm{C}$ between May and June. Relative air humidity remains high and reaches $90 \%$ near the coast, with minima above $15 \%$ in the inland parts of the Niayes.

\section{Water and soil resources:}

The Niayes area is devoid of permanent surface water. Water resources in these areas consist mainly of groundwater. The main water reserve is a shallow aquifer of good quality that extends throughout the area. This aquifer is essential in supplying water for all requirements (Touré and Seck, 2005). Average annual precipitation is low and rarely exceeds $300 \mathrm{~mm} /$ year (ANACIM, 2016). However, off-season rains often occur in dry seasons, especially during cold periods (December, January, and February). These rainfalls resulting from intrusion of polar air masses, irregular and scarce, are nevertheless of great importance for the practice of off-season crops in this environment (Fall and Fall, 2001).

Soils in Gandiolais region are also characterized by salinity, which reduces the yields of the crops grown. Farmers sometimes stop working their land because of the salinity of the soil or water. The overall geomorphology is a mosaic of dunes and interdune basins with flat bottoms, more or less incised, where soils are formed with little evolution of input, poor and very susceptible to erosion (Diallo et al., 2015). Local names make it possible to characterize its topographic profile. Thus, locally, the reverse side of the lowland is called Dior (sandy soil), the slope is called Mbamba (sandy-clay soil) and the bottom is locally called Khour (clay soil) (Seck et al., 2017). 


\section{Data:}

Data collected in this study come from surveys carried out on plots in the five lowlands but also from measurements of water volume and yields collected.

\section{Sampling frame for data collection:}

The sampling frame consists of a list of 216 plots from the five lowlands. Plots are distributed among the five (05) lowlands (Table 1).

Table 1:- Plots distribution by lowland.

\begin{tabular}{|l|l|}
\hline Lowlands & Number of plots \\
\hline DeurDiabi & 110 \\
\hline Lac Kalassane & 36 \\
\hline BoulAyni & 32 \\
\hline FersetNdoye & 23 \\
\hline Nguéthiouro & 15 \\
\hline Total & $\mathbf{2 1 6}$ \\
\hline
\end{tabular}

\section{Determination of sample size:}

Sample size was calculated using the formula of Giezendanner (2012) (Eq. 1).

$\mathbf{n}=\frac{(\mathbf{t})^{2} * \mathbf{N}}{(\mathbf{t})^{2}+(2 \varepsilon)^{2}(\mathbf{N}-\mathbf{1})} \quad(\mathrm{Eq} .1)$

Where $\mathrm{n}$ is sample size, $\mathrm{t}$ is margin coefficient deduced from the confidence rate, $\mathrm{N}$ is Size of target population (total number of plots), and $\varepsilon$ is margin of error. $\varepsilon$ represents the range of certainty within which answers obtained are accurate. It is generally between 1 and $10 \%$;

For this study, margin of error of $\varepsilon=5 \%$ and $95 \%$ confidence interval (which implies an inferred margin $\mathrm{t}=1.69$ ) were used to calculate the sample size. This resulted in a sample size of 123 plots.

\section{Sampling rate:}

To determine sample size at each lowland, a sampling rate was calculated from equation 2:

$\mathbf{T}=\frac{\mathbf{n}}{\mathbf{N}}($ Eq. 2$)$

Where $\mathrm{T}$ is Sample rate, $\mathrm{n}$ is sample size, and $\mathrm{N}$ is target population size (total number of plots).

This gives a sampling rate $\mathrm{T}$ of $56.9 \%$. It allowed us to determine the number of households to be surveyed in each lowland (Table 2).

Table 2:-Sample size by lowland.

\begin{tabular}{|l|l|l|}
\hline Lowland & Nomber of plots & Sample size \\
\hline DeurDiabi & 110 & 63 \\
\hline Lac Kalassane & 36 & 20 \\
\hline BoulAyni & 32 & 19 \\
\hline FersetNdoye & 23 & 13 \\
\hline Nguéthiouro & 15 & 9 \\
\hline Total & $\mathbf{2 1 6}$ & $\mathbf{1 2 3}$ \\
\hline
\end{tabular}

Questionnaire elaboration, testing and data collection:

Questionnaire was developed for data collection. Following the development of this data collection tool, a simulation (survey scenario) of the administration of data collection tool was conducted. Subsequently, questionnaire administration was field-tested in Yibalowland located in the study area but not included in the selected study lowlands. Tests were conducted to ensure an understanding of questions and issues to be considered during interviews.

Data collection was conducted from August 26 to September 19, 2019, with a semi-structured questionnaire administered to producers owning plots. 


\section{Determination of total volume of water applied:}

The total volume of water used was estimated from the number of buckets used per irrigation unit and per irrigation day, the volume of buckets and the number of irrigation days per crop throughout a season. The number of irrigation days (Eq. 3) was obtained from the frequency of irrigation and the crop cycle of speculation. These two parameters were obtained from field surveys. The number of days of irrigation was obtained from crop cycle and number of rested days (without irrigation).

Numberof dayofirrigation $=$ Cropcycle - Numberof restday (Eq. 3)

The number of irrigation days was multiplied by the volume of water applied per irrigation day per unit to determine the total volume of irrigation water applied to a unit (TVU) (Eq. 4) throughout the season for a given crop.

TVU $=$ Numberofbuckets $*$ Volumeofabucket $*$ Numberofirrigationday $(E q .4)$

Number of buckets per unit was obtained from field surveys and area harvested was obtained by measurement from the Field Area Measure (FAM) application. Unitary area (Sp) was calculated from dimensions such as length (L) and width (l) of each unit obtained using a decameter. Length (L) was multiplied by width (l) to obtain the unit area $(\mathrm{Sp})$, as shown in equation 5 :

$\mathbf{S p}=\mathbf{L} * \mathbf{l} \quad$ (Eq. 5)

Where $\mathrm{Sp}$ is surface area of units $\left(\mathrm{m}^{2}\right), \mathrm{L}$ is length of units $(\mathrm{m})$, and $\mathrm{l}$ is width of units $(\mathrm{m})$.

Total volume is divided by the area of the unit and then multiplied by the area cultivated (Eq. 6) to obtain the volume brought in throughout the season.

$\mathbf{V e}=\frac{\mathbf{s e}}{\mathbf{s p}} * \mathbf{V T P} \quad$ (Eq. 6)

Where Ve is Volume of water (m3/ha), Se is Cultivated area (ha), Sp is Surface area of units (ha), and VTP: Total volume of water per unit $\left(\mathrm{m}^{3} / \mathrm{ha}\right)$.

\section{Yield determination:}

Yield was determined based on production and area cultivated. Production was obtained from interviews and calculations based on the number of traps obtained per area cultivated and the weight of the trap. Number of traps was multiplied by weight of each trap to determine production. This production corresponds to the quantity of products expressed in kg per area cultivated. Production was divided by cultivated area expressed in ha and then converted into tonnes $(t)$ in order to estimate the average yield of each speculation in Gandiolais area.

\section{Water productivity calculation:}

To calculate water productivity, the formula proposed by (IWMI, 1997 (Dembélé et al., 2001) (Eq. 7) was used :

$\mathbf{P E}=\frac{\mathbf{P}}{\mathrm{Ve}} \quad$ (Eq. 7)

Where PE is Irrigation Water Productivity $\left(\mathrm{kg}^{-\mathrm{m}^{-3}}\right)$, Ve is Volume pumped or Volume of water abstracted at source for irrigation $\mathrm{m} 3 / \mathrm{ha}$, and P: Yield ( $\mathrm{kg} / \mathrm{ha})$.

\section{Results and Discussion:- \\ Water volume supplied:}

Figure 2 shows the variation in volumes of water brought into each lowland during growing season. This volume of water was estimated after transplanting the plants, without taking into account quantities of water supplied during nursery irrigation. 


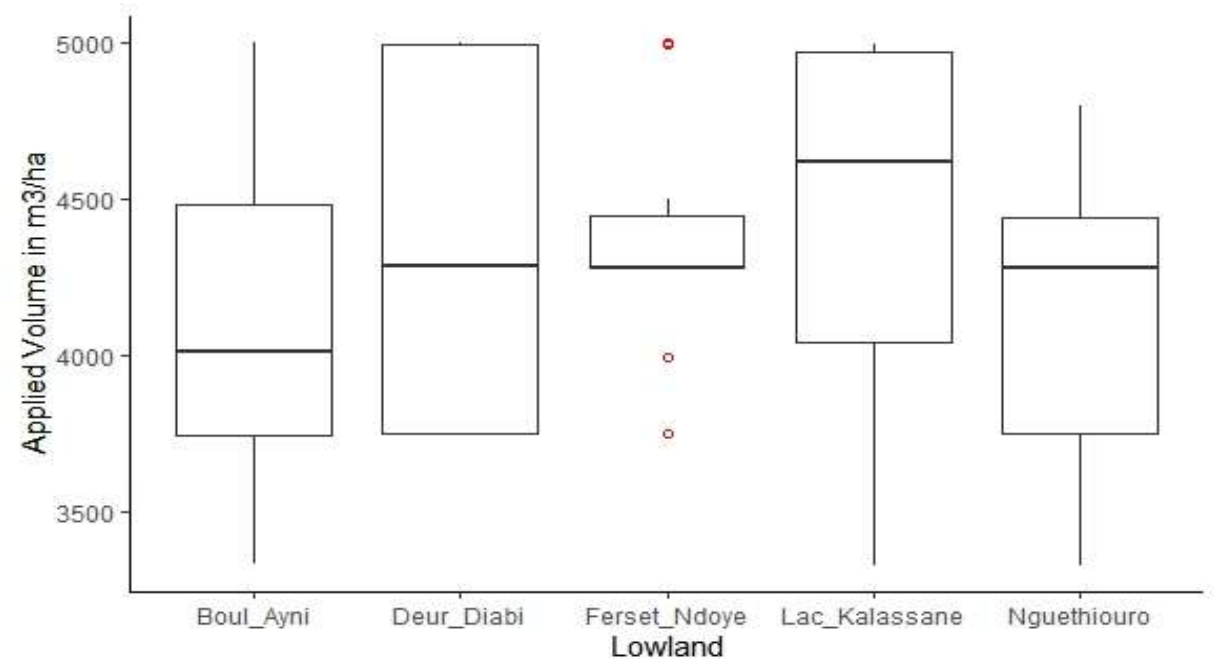

Figure 2:- Variation in water volumes applied per lowland during growing season in Northern Niayes area.

Results show that the volumes of water applied are variable within the same lowland. This variation is more pronounced in Boul Ayni and Lac Kalassane lowlands and less so in Ferset lowland. Thus, volumes of water applied vary between about 3330 and $5000 \mathrm{~m}^{3} / \mathrm{ha}$ in BoulAyni lowland, 3746 and $5000 \mathrm{~m}^{3} / \mathrm{ha}$ in DeurDiabi lowland, 3800 and $5000 \mathrm{~m}^{3} / \mathrm{ha}$ in FersetNdoye lowland, 3333 and $4800 \mathrm{~m}^{3} / \mathrm{ha}$ in Lac Kalassane lowland and 3330 and $4750 \mathrm{~m}^{3} / \mathrm{ha}$ in Nguéthiouro lowland. With the exception of BoulAyni lowland, 50\% of farmers provide a volume of water higher than $4000 \mathrm{~m}^{3} / \mathrm{ha}$, or even higher than $4500 \mathrm{~m}^{3} / \mathrm{ha}$ in Lac Kalassane lowland.

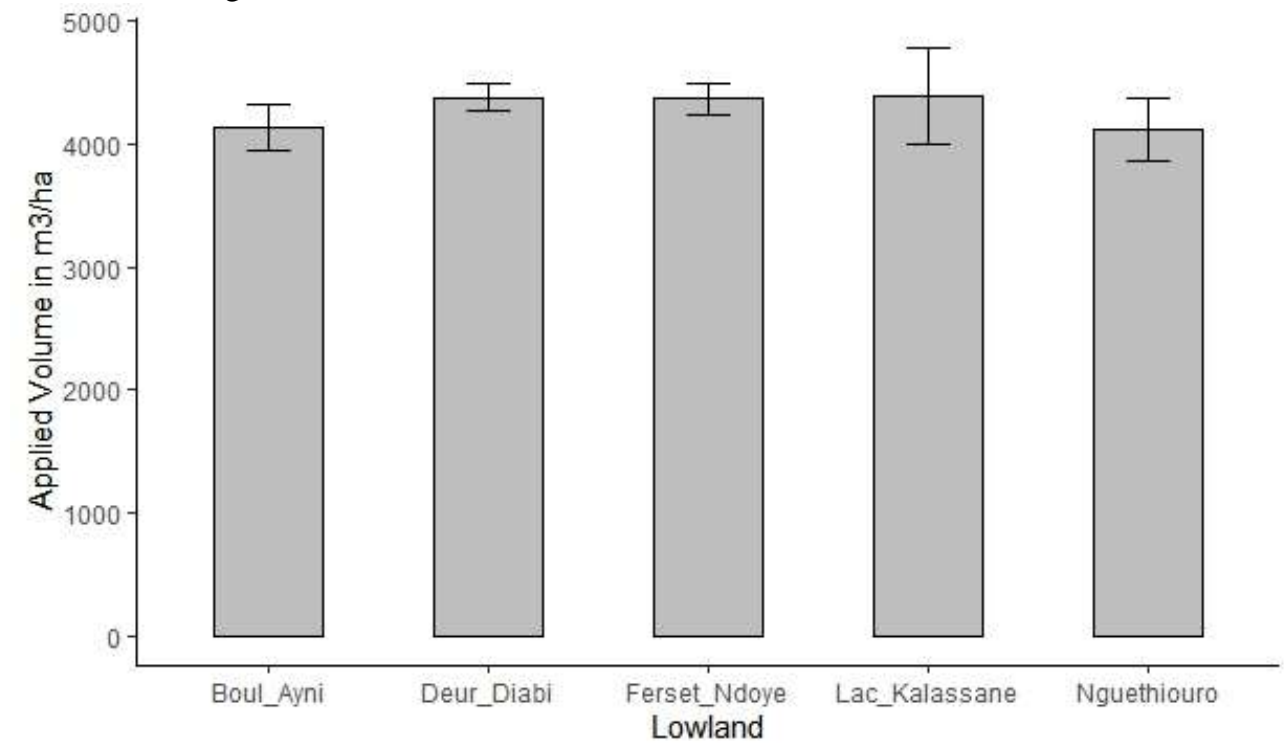

Figure 3:- Average volume of water applied per hectare per lowland in the Nord Niayes area.

Results (Figure 3) show that the average volume of water applied to the tomato cultivation reached $4000 \mathrm{~m}^{3} / \mathrm{ha}$ in all lowlands. The highest mean volume was obtained in Lac Kalassane lowland; it is estimated at $4391 \mathrm{~m}^{3} / \mathrm{ha}$ in this area. However, the lowest mean volume was observed in Nguéthiouro lowland where it is estimated at $4119 \mathrm{~m} 3 / \mathrm{ha}$. In DeurDiabi, FersetNdoye and BoulAyni lowlands, the mean values of water volume supplied are estimated at 4370,4365 and $4130 \mathrm{~m}^{3} / \mathrm{ha}$, respectively. However, similarly to the other lowlands, the volumes of water brought in by the majority of farmers are above the average value. For this purpose, it is estimated at about $55 \%, 65 \%$, and 95\%, respectively in DeurDiabi, BoulAyni, and FersetNdoye lowland.

The small amount of water provided to Nguéthiouro lowland can be explained by the short duration of the late phase (ripening) of the crop. Indeed, plants tend to dry out just after two to three harvests. As a result, irrigation is stopped 
well before the end of the crop cycle of the plant. Regarding FersetNdoye lowland, most farmers practice manual extraction water source techniques. Consequently, access to water is difficult in these conditions, which may be the reason for moderate use of water in this lowland compared to others. BoulAyni is also a lowland in which water volumes provided to tomato are low. In this lowland more than $80 \%$ of farmers use manual dewatering technique, and groundwater table from which water used exclusively for irrigation comes is deeper than in the other lowlands. In fact, daily quantities of water extracted from wells are relatively small due to the arduous nature of manual water extraction from wells, which does not allow them to have a significant difference between two successive days of irrigation. Furthermore, the quantities of water provided during growing season higher in Lac Kalassane lowland may be explained by the fact that farmers in this area are more advanced in terms of equipment used for irrigation compared to other basins. For example, they practice more motorized dewatering techniques, which facilitates their access to water for irrigation.

\section{Yields:}

Results show that yields obtained vary on average between 18 and 27 t/ha, for an average of $22 \mathrm{t} / \mathrm{ha}$ (Figure 4).

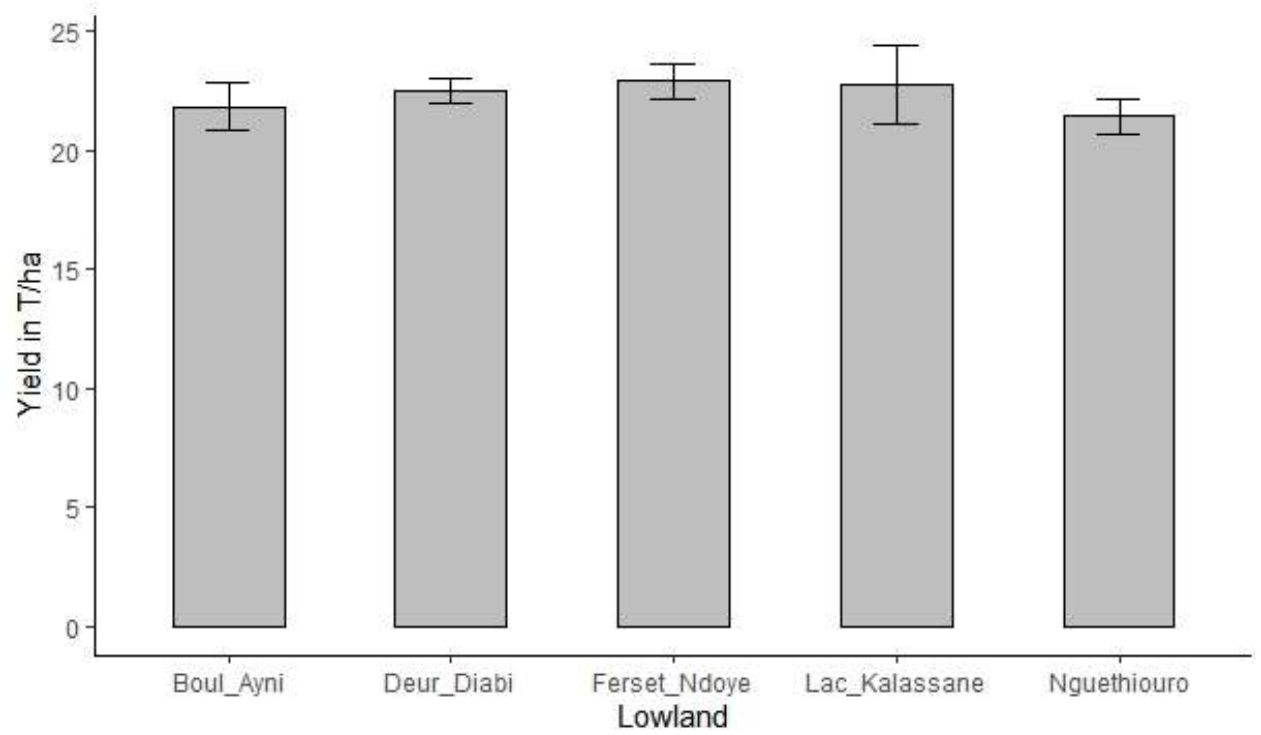

Figure 4:-Tomato yield per hectare per lowland in the Nord Niayes area.

The average tomato yield in Gandiolais is almost homogeneous, varying from 19 to 26 t/ha in DeurDiabi, from 18 to $26 \mathrm{t} / \mathrm{ha}$ in BoulAyni, from 18 to $25 \mathrm{t} / \mathrm{ha}$ in Lac Kalassane, from 19 to $27 \mathrm{t} / \mathrm{ha}$ in FersetNdoye and from 20 to $24 \mathrm{t} / \mathrm{ha}$ in Nguéthiouro lowlands. The lowest yield values were observed in BoulAyni and Lac Kalassane lowlands (18 t/ha). At Lac Kalassane, tomato cultivation is under heavy nematode pressure. This could explain the low yield recorded in this area.

However, these yields are more or less acceptable compared to the average tomato yield obtained in Senegal River valley, which is estimated at $24.3 \mathrm{t} / \mathrm{ha}$ (Huat, 2006). However, they are well below yields estimated between 45 and 65 t/ha indicated by Doorenbos and Pruit (1977) for arid and semi-arid regions.

\section{Water productivity:}

Figure 5 shows variations in water productivity of the tomato crop in the five lowlands studied. 


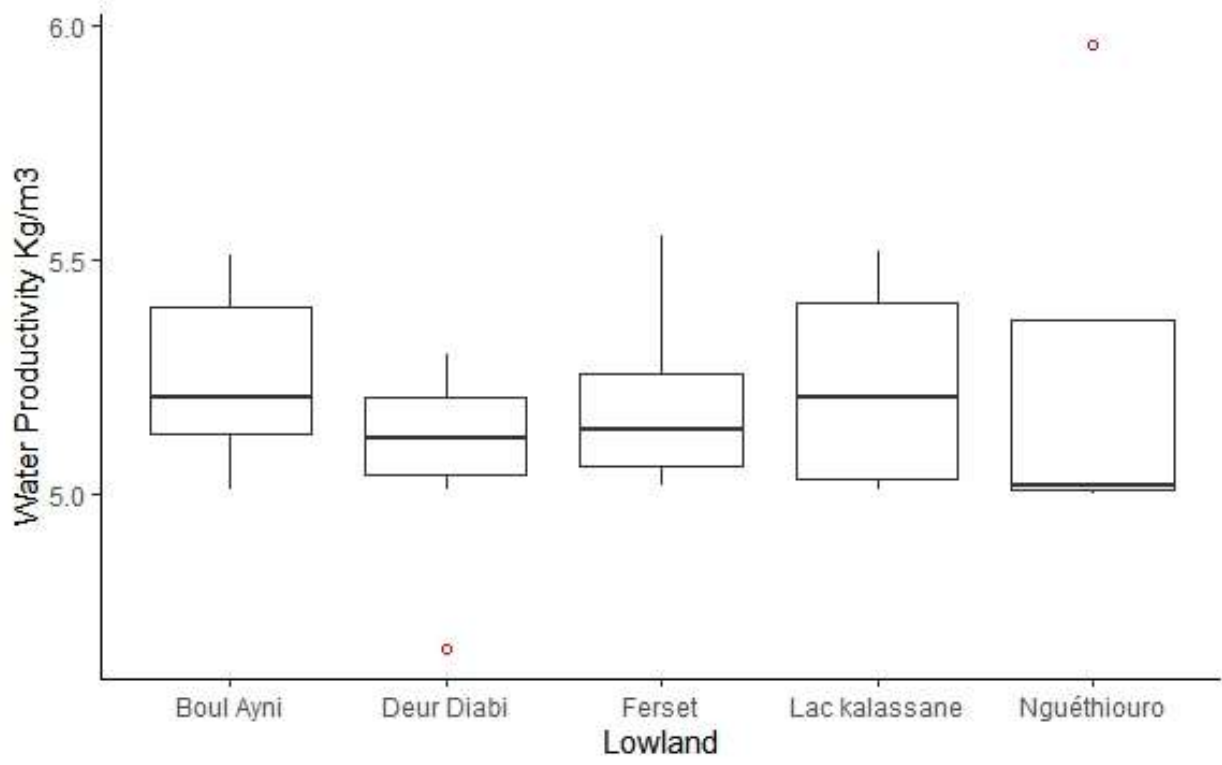

Figure 5:- Variation in water productivity of tomato by lowland in the Northern Niayes area.

Results in Figure 5 show that tomato water productivity is more variable in the Nguéthiouro, Lac Kalassane, and BoulAyni lowlands. It ranged from 5.01 to $5.51 \mathrm{~kg} / \mathrm{m}^{3}$ in BoulAyni lowland, 5.01 to $5.30 \mathrm{~kg} / \mathrm{m}^{3}$ in DeurDiabi lowland, $5.00-5.96 \mathrm{~kg} / \mathrm{m}^{3}$ in Nguéthiouro lowland and 5.01 to $5.52 \mathrm{~kg} / \mathrm{m}^{3}$ in Lac Kalassane lowland. In addition, $50 \%$ of farmers in DeurDiabi and FersetNdoye lowlands and more than 50\% in BoulAyni and Kalassane Lake lowlands have productivity greater than or equal to about $5.15 \mathrm{~kg} / \mathrm{m} 3$.

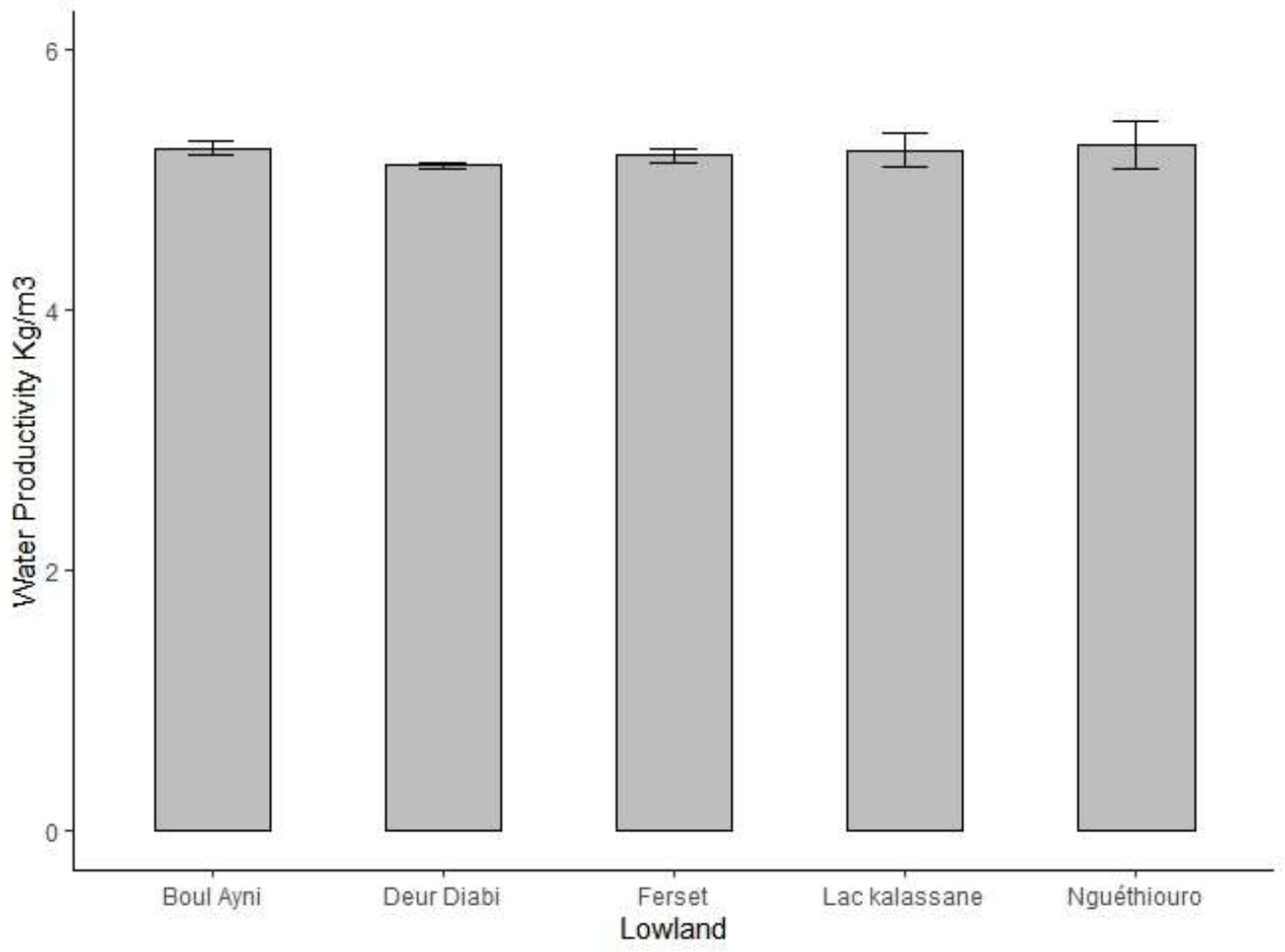

Figure 6:- Average tomato water productivity per lowland in the Northern Niayes area.

Figure 6 shows that the average value of water productivity of the tomato reaches $5.27 \mathrm{~kg} / \mathrm{m}^{3}$ in Nguéthiouro lowland and $5.25 \mathrm{~kg} / \mathrm{m}^{3}$ in Lac Kalassane lowland. The mean values of water productivity in FersetNdoye, BoulAyni, and DeurDiabi lowlands are $5.23,5.19$ and $5.13 \mathrm{~kg} / \mathrm{m}^{3}$ respectively. 
Differences in water productivity between lowlands are related to differences in applied water volumes and yields.

Water productivities in this area are generally low corresponding to the lower value of water productivity ranges proposed by (Molden et al., 2016). These reference values range from 5 to $20 \mathrm{~kg} / \mathrm{m}^{3}$. A study realized in Sahelian zone in Mali, (Coulibaly et al., 2018) obtained water productivity of $4.52 \mathrm{~kg} / \mathrm{m}^{3}$ in dry season tomato crop manually irrigated with mineral fertilization (NPK) with a yield level of $38 \mathrm{t} / \mathrm{ha}$. This productivity reaches $9.34 \mathrm{~kg} / \mathrm{m}^{3}$ with mineral treatment (NPK) and drip irrigation system for a yield level of $63 \mathrm{t} / \mathrm{ha}$. Also, water productivity was estimated at $10.58 \mathrm{~kg} / \mathrm{m}^{3}$ in Nile Delta in Egypt (El-Marsafawy et al., 2018). These results obtained confirm that water productivity is generally low in the Northern Niayes area. This very low water productivity is mainly related to the very high quantities of water applied per season in addition to the low yields obtained following tomato harvest in this area.

\section{Conclusion:-}

The objective of this study is to assess tomato irrigation water productivity in the northern Niayes area in Senegal, in the market gardening lowlands of Gandiolais region.

A survey was carried out on a sample of 123 plots in DeurDiabi, BoulAyni, Lac Kalassane, FersetNdoye, and Nguéthiouro lowland and the total volumes of water applied, yields and water productivity were determined for each plot.

Results show that water productivity in Gandiolais area is relatively low. They result in very high volumes of water applied compared to the net water requirements and relatively low yields. Productivity is between 5.00 and 5.96 $\mathrm{kg} / \mathrm{m} 3$ with an average of $5.18 \mathrm{~kg} / \mathrm{m} 3$. Water productivity is lower in Deur Diabi lowland and higher in BoulAyni, Kalassane Lake and Nguéthiouro lowlands, respectively. The results obtained are in fact consequence of a very complex system that includes collection means and techniques of water extraction, irrigation system, as well as irrigation water management.

However, water productivity can be considered as a very important tool that can be used in water management. Thus, it is a useful indicator in agriculture that can be further studied to take into account cropping practices, fertilization, as well as predators and disease management.

\section{Acknowledgements:-}

Authors are grateful to WAGRINNOVA project for the support of this research

\section{References:-}

1. ANACIM (Agence National de L'Aviation Civile et de la météorologie), 2016

2. ANSD. (2017). Situation économique et social du Sénégal en 2014

3. Arouna A., Awi E., et Azouma Y. O. (2018) “Amélioration de la productivité de l'eau en culture irriguée de tomate (Lycopersicumesculentum) en saison sèche au Sud-Togo"

4. Coulibaly D., Diallo D., Dembélé D. (2018). Productivité de l'eau en culture de tomate de saison sèche en zone sahélienne du Mali. Symposium maliensur les sciences appliquées. 11

5. Dembélé Y., Ouattara S., Keita A. (2001). Application des indicateurs « approvisionnement relatif en eau » et « productivité de l'eau » à l'analyse des performances des petits périmètres irrigués au Burkina Faso. Irrigation et Drainage, $50: 309-321$

6. Diallo M. D., Ndiaye O., Mahamat Saleh M., Tine A., Diop A., Guissé A. (2015). Etude comparative de la salinité de l'eau et des sols dans la zone nord des Niayes (Sénégal). African Crop Science Journal, Vol. 23, No. 2, pp. 101-111

7. Doorenbos J., Pruit W. O. (1977). Lignes directrices pour prévoir les besoins en eau des cultures. Document $\mathrm{n}^{\circ}$ 24 de la FAO sur l'irrigation et le drainage, Organisation des Nations Unies pour l'Alimentation et l'Agriculture, Rome, Italie

8. El-Marsafawy S.M., Swelam A. and Ghanem A. (2018). Evolution of Crop Water Productivity in the Nile Delta over Three Decades (1985-2015)

9. Fall S.T, Fall A.B. (2001). Cités horticoles en sursi? L'agriculture urbaine dans les grandes Niayes au Sénégal. IDRC, Dakar. 
10. FAO. (2001). Le rôle de l'agriculture dans le développement des pays les moins avancés et leur intégration à l'économie mondiale

11. FAO. (2011). L'état des ressources en terres et en eau pour l'alimentation et l'agriculture dans le monde.Gérer les systèmes en danger, Organisation des Nations Unies pour l'Alimentation et l'Agriculture, Rome, Italie.

12. FAO. (2005). Profil de pays - Sénégal

13. HORTICA. (2004). Renforcement des capacités de micro-irrigation pour l'intensification de l'horticulture Zone des Niayes : Rapport d'identification de projet.

14. Huat J. (2006). Facteurs limitatifs du rendement de la tomate industrielle en périmètres irrigués au Nord Sénégal. Cahiers Agricultures 15 : 293-300

15. IWMI. (1997). Améliorer les performances des périmètres irrigués. In : Actes du séminaire régional du Projet management de l'irrigation au Burkina Faso, 24-26 juillet 1996, IWMI (International Water Management Institute), Ouagadougou, Burkina Faso

16. M. K. Van Ittersum et al. (2016). Cansubsaharan Africa feed itself

17. Molden D., Oweis T. Y., Pasquale S., Kijne J. W., Hanjra M. A., Bindraban P. S., Bouman B. A. M., Cook S., Erenstein O., Farahani H., Hachum A., Hoogeveen J., Mahoo H., Nangia V., Peden D., Sikka A., Silva P., Upadhyaya A., Zwart S. (2007)."Tendances en matière d'eau et de développement agricole" In : D. Molden (Ed.) L'eau pour l'alimentation, l'eau pour la vie : Evaluation complète de la gestion de l'eau en agriculture, Earthscan et Institute International de la Gestion de l'eau. Londres et Colombo

18. Molden D. Oweis T. Steduto P. Bidraban P. Hanjra. M.A. Kijne J. (2010) "Améliorer la productivité de l'eau agricole : entre optimisme et prudence", Gestion de l'Eau Agricol, 97 : 528-535

19. Ndiaye, O., Diallo, A., Matty,F., Thiaw, A., Fall, R.D., Guisse, A. (2012). Caractérisation des sols de la zone des Niaye de Pikine et de Saint Louis (Sénégal).

20. OCDE/FAO. (2016). Perspectives agricoles de l'OCDE et de la FAO 2016-2025, Edition OCDE, Paris. http://dx.doi.org/10.1787/agr_outlook-2016-fr,

21. O. Serdeczny, S. Adams, F. Baarsch, D. Coumou, A. Robinson, W. Hare, M. Hare, M. Schaeffer, M. Perrette, J. Reinhardt .(2016). Climate change impacts in Sub-Saharan Africa: from physical change to their repercussions

22. Playan, E., Mateos L. (2006). Modernisation et optimisation des systèmes d'irrigation pour augmenter la productivité de l'eau",Gestion de l'eau Agricole", $80: 100-116$

23. Rowhani P, Lobell D.B, Lindermanc M, Ramankutty N. (2011).Variabilité climatique et production agricole en Tanzanie. Météorologieagricole et forestière., $151: 449-460$

24. Seck M. S., Mateos L., Gomez Macpherson H., Bodian A., Mbaye M., Sy K., Ly B. (2017).Étude de la durabilité des systèmes de production et de la gestion de l'eau dans le Gandiolais (zone nord des Niayes) dans un contexte de changement climatique et d'insécurité alimentaire. Rapport final provisoire, 73

25. Touré S, Seck M S. (2005)."Intégration horticulture-élevage dans les systèmes agricoles urbaines de la zone des Niayes (Sénégal) ” In A.S. Fall, C. Gueye (eds) Urbain - Rural l'hybridation en marche, Enda tiers-monde, Dakar, p. 445-478

26. Yunana D.A.,Shittu A.A., Ayuba S., Bassah E.J., and JoshuaW.K. (2017). "Climate change and lake water resourcesinsub-saharan Africa: Case study of lake Chad and Lake Victoria", Nigerian Journal of Technology (NIJOTECH), vol. 36, no. 2, pp. 648-654. 